\title{
Cassava Smallholders' Participation in Contract Farming in Nakhon Ratchasrima Province, Thailand
}

\author{
*Siros Tongchure, Nam Hoang \\ University of New England, Armidale, NSW, Australia \\ *stongchu@myune.edu.au
}

\begin{abstract}
The most important raw materials for bio-ethanol in Thailand are cassava, sugar cane and molasses. However, cassava has been promoted as a feed stock for ethanol due to the minimal inputs for planting, high productivity and all-year planting and harvesting. The most important factor influencing ethanol using cassava production is the price of cassava feedstock. Contract farming could decrease production costs, increase efficiency in markets, provide lower interest rates, decrease risk management and create symmetric information for cassava smallholders. The scope of this study includes cassava cultivation and factors influencing contract participation using logit analysis. Results from a survey consisting of 130 non-contractors and 127 contractors showed there was a verbal communication between farmers and agricultural cooperatives and written contractual agreement between agricultural cooperatives and processors. In addition, contract participation is significantly influenced by gender of household head, education of household members, number of agricultural groups, input costs, machinery costs, incomes and credit access.
\end{abstract}

Keywords: Contract farming, Smallholders' participation, Cassava production, Nakhon Ratchasrima Province and Thailand

\section{Introduction}

Since fossil fuel prices were very high in 2004, the Thai government modified programs and policies leading to increases in biofuels production and consumption. A plan for Thailand was developed covering bio-ethanol production from the raw materials and increasing the areas of bio-ethanol raw materials. Thus, the Thai government has promoted using E20 and E85 and has developed a price policy to make bio-ethanol cheaper than regular gasoline (Bloyd, 2009). The most important raw materials for bioethanol in Thailand are cassava, sugar cane and molasses. However, cassava has been promoted as a feed stock for bio-ethanol in Thailand due to the minimal inputs for planting, high productivity and all-year planting and harvesting (Zhang \& Han, 2003; Sriroth and Piyachomkwan, 2008). Consequently, in 2010, there were 24 registered ethanol plants in Thailand which produced 8.39 million litres per day (Preechajarn and Prasertsri 2010). There are three important factors influencing cassava production for bio-ethanol. First, the price of cassava feedstock which is the biggest cost in ethanol production $(59.29 \%)$, followed by net operating cost (22.32\%) and investment cost (18.43\%) (Nguyen \& Gheewala, 2008; Seumpakdee 2009; Bell \& Silalertruksa, 2010; Suthamma and Chumnong 2011). Second, there are difficulties arising from cassava production such as the quality of raw materials (Nualvatna 2003), lack of labour (Office of Agricultural Economics 2007) and aphid infestation in cassava crops (Department of Export Promotion 2010). Finally, there are some agricultural marketing problems in Thailand (Nishimura 2003;Nualvatna 2003). Therefore, choosing contract farming may be the best solution for cassava production because of contracting which may decrease the cassava production costs, reduce transaction cost in markets, lower interest rate, decrease risk management and symmetric information.

\section{Literature Review}

Contract farming has expanded to become a significant and expanding form of agricultural food industry in developed countries (Martinez and Reed 1996). For example, contract farming accounted for 39\% of the total value of US agricultural production in 2001, a substantial increase over the $31 \%$ estimated for 1997 (Young and Hobbs 2002). Similar to in Germany, contract farming accounts for $38 \%$ of the production of dairy, poultry and moreover, contracts cover $75 \%$ and $23 \%$ of broiler production in Japan and South Korea, respectively (Young and Hobbs 2002). In addition, in Southeast and South Asia, contract farming has also increased rapidly in recent decades (Swinnen and Maertens 2007). For example, contract farming in Malaysia is also widespread, mainly based on state-promoted out-grower 
arrangements (Morrison \& Murray, 2006). In East Asia, contract farming is also widespread. For example, in China, the government has supported contract farming since 1990 with dramatic results: by 2001, over 18 billion hectares were planted under contract-farming arrangements, an increase of around $40 \%$ from 2000 (Guo and Jolly 2009).

For farmers, contract farming has increased cash crop production, rural employment, social facilities and rural infrastructure (Glover 1990; Baumann 2000; Singh 2011) and has also led to better employment opportunities for women workers (Singh 2011). Furthermore, the main opportunity from contract farming is the promise of higher incomes. But, while important, this is not the sole criterion; for example, both Masakure and Henson (2005) and Guo and Jolly (2009) pointed out that stability and technical knowledge were the most important reasons why farmers join contract-farming initiatives. Contract farming can also provide many additional benefits and opportunities: it can increase on-farm diversification; technical assistance and knowledge transfer can spill over onto adjacent fields and into nearby villages; by-products from contract farming can be used for other farming activities; it can simplify marketing decisions, thus improving efficiency; it can stimulate the broader commercialization of smallholder farming; and, finally, contracts can be used as a form of collateral for credit. Additionally, contract farming also offers numerous opportunities for farmers including: 1) allowance access to a reliable market, 2) provide guaranteed and stable pricing structures, and 3) provide access to credit, inputs, production and marketing services (Prowse and Thirion, 2012).

For firms, the opportunities provided by contract farming are clear and convincing (Prowse and Thirion 2012), including: 1) increasing reliability in supply quantity and quality, 2) the off-loading of production risk on to farmers, 3) greater control over the production process and crop attributes to meet standards and credence factors, 4) reducing co-ordination costs, as a more regular and stable supply permits greater co-ordination with wider activities, and 5) economies of scale in procurement, via the provision and packaging of inputs. Although Swinnen and Maertens (2007) posit that the higher transaction costs and investment constraints would tend to limit smallholder participation in contract farming, a clear rationale for contracting smallholders can be found in the literature on the relative merits of small versus large farm production in sub-Saharan Africa (Ellis and Biggs, 2002). Small farms are frequently the most efficient agricultural producers and have advantages over large farms in terms of labour-related transaction costs, in particular, supervision and motivation (Prowse and Thirion, 2012). In terms of poverty reduction, contracting with smallholders can reap large dividends: small farms are generally owned and operated by the poor, often using locally-hired labour and often spend income within nearby locales, creating multipliers (Hazell \& Poulton, 2006).

\section{Methodology}

In this study, there are three steps to survey sample households. The first step is selection of sample region. The north-eastern region was the largest area for cassava planting followed by the eastern region and the central plain region. The next step is selection of province and districts. Nakhon Ratchasima province has been the largest areas of cassava planting in Thailand since 2006, accounting for 1.4161 million rai ${ }^{1}$ in 2010 (Office of Agricultural Economics 2008; Office of Agricultural Economics 2011). Then, Dan Khuntod, Khon Buri and Soeng Sang will be selected as sample districts for the survey as they were the largest areas of cassava production and they had the largest number of cassava farmers (Department of Agriculture Extension 2011). The final stage was choice of sample households. 257 households were randomly selected. A total of 127 farmers under contracts and 130 farmers non-under contracts were interviewed. The standard econometric method for explaining discrete dependent variables such as yes or no is a binary choice model. Two basic techniques are used to estimate this model: 1) maximum likelihood methods (non-linear estimates) such as probit and logit model and 2) least square regression analysis (linear estimates) such as the linear probability model. With non-linear estimates, the most common frameworks used in econometric applications are probit and logit models. The probit model is based on the standard normal distribution while the logit model is based on the logistic distribution. However, for independent variables with very small values, the logistic distribution tends to give higher probabilities to their likelihood. Logit model is popular because the logit model is simpler compared to the probit model (Train 1995; Crown 1998; Fabra and Schmidheiny 2010) because the probit model requires the use of integral calculus to calculate the cumulative normal probabilities, whereas the logit model has a closed form that permits these probabilities to be calculated without integration. However,

${ }^{1}$ A Thai unit of area, 1 rai equal to 1,600 square metres 
both models are nonlinear, computationally burdensome and more complicated in comparison with the linear probability model (Crown 1998). In this regard, most applied economists find that in most applications, choices between two models are not likely to make much difference to results.

\section{Results and Discussion}

Results from the calculation of key variables for human capital of 130 non-contractors and 127 contractors are shown as Table 1.

Table 1: Key Variables for Human Capital of Non-contractors

\begin{tabular}{llll}
\hline & Non-contractors & Contractors & Pr. \\
\hline Agronomic factors in cassava production & & & \\
Present variety of cassava (\%) & & & \\
- KU 50 & 63.85 & 3.94 & - \\
- Rayong 5 & 2.31 & & - \\
- Khan-Daeng & 1.54 & 49.61 & \\
- Rayong 80 & 32.31 & 46.46 & \\
- Houy Bong 60 & 10.98 & 11.43 & $0.0017^{* *}$ \\
Planting period (months) & 21.32 & 15.09 & $0.0000^{* *}$ \\
Length of stakes (cm) & 3.12 & 3.98 & $0.0000^{* *}$ \\
Age of stakes (weeks) & 43.40 & 49.78 & $0.0950^{\text {ns }}$ \\
Chemical fertilizers (kg) & 236.55 & 113.25 & $0.0000^{* *}$ \\
Manures (kg) & 1.04 & 1.07 & $0.9236^{\text {ns }}$ \\
Herbicides (litres) & 1.28 & 0.98 & \\
Pesticides (litres) & & & $0.0282^{*}$ \\
Human capital & 49.04 & 48.83 & \\
Age of household head (years) & 37.86 & 24.92 & $0.8756^{\text {ns }}$ \\
Average age of household member (years) & 6.43 & 7.26 & $0.0000^{* *}$ \\
Household head schooling year & & & $0.0401^{*}$ \\
& 7.13 & 20.50 & $0.0000^{* *}$ \\
Household members schooling year & 14.70 & 14.60 & $0.9242^{\text {ns }}$ \\
Experience in growing cassava (years) & & & \\
Social capital & 0.83 & 2.29 & $0.0000^{* *}$ \\
Agricultural organization (groups) & 10.00 & 10.66 & $0.3402^{\text {ns }}$ \\
Years of participation & & & \\
Farm attributes & 24.75 & 36.62 & $0.0220^{*}$ \\
Size of land (rai) & 16.95 & 16.35 & $0.6728^{\text {ns }}$ \\
Years of owner or management & $330,808.70$ & $703,898.80$ & $0.0000^{* *}$ \\
Assets value (baht) & & &
\end{tabular}

Source: Calculated from the survey

Agronomic Factors in Cassava Production: Cassava is a tropical root crop which grows in a broad area of rainfall and produced by smallholder farmers (Howeler \& Oates, 2000). It takes eight months under suitable climate conditions and grows best in direct sunlight within soil pH between 4.0 and 8.0 (Kuiper \& Ekmekci, 2007). There are four steps of cassava planting (Nguyen \& Gheewala, 2008): land preparation, planting, crop maintenance (weed control, fertilization) and harvesting includes loading. There are five most important varieties of cassava cultivation in Thailand (Senadee \& Aksornneum, 2008); Rayong 60, Kasetsart 50, Rayong 5, Huay Bong 60 and Huay Bong 80 . There was $63.85 \%$ of non-contractors growing "Kasetsart 50", followed by "Houy Bong 60" and "Rayong 5" which accounted for $32.31 \%$ and $2.31 \%$. The best planting period of cassava not only depends on the climate conditions at planting time; the best planting period also depends on marketing conditions at expected harvesting time. The cassava root price depends on the starch content, so cassava farmers want to maximize both starch content and yield at harvesting time. Moreover, cassava prices also rely on market conditions. Thus, farmers harvest their products in different months in order to get higher prices.

Over $98 \%$ of contractors grew cassava by good technique with $15 \mathrm{~cm}$ length and 4 weeks stored to obtain a minimum of $80 \%$ germination (George \& Mohankumar, 2000; Howeler 2007). Cassava is extremely 
tolerant of acid soils. However, the nutrient content in the soil might be depleted; yields would be decreased if farmers grow cassava on the same land for many years unless farmers return the nutrients in the form of chemical fertilizers or manures. The non-contractors apply 15-15-152, 46-0-0 and 16-8-8 chemical fertilizer with about $25 \mathrm{~kg} / \mathrm{rai}$. In contrast, contractors apply around $50 \mathrm{~kg} / \mathrm{rai}$. However, for manures, as a rough comparison, $50 \mathrm{~kg}$ of chemical fertilizer formulated 15-15-15 contains nearly the same amounts of $\mathrm{N}, \mathrm{P}$ and $\mathrm{K}$ as $1,000 \mathrm{~kg}$ of wet pig manure (Howeler 2000). Contractors apply only chicken manure with $125 \mathrm{~kg} /$ rai. However, animal manures might be an important source of S, Ca, Mg and other micronutrients, but contain very low amounts of $\mathrm{N}, \mathrm{P}$ and $\mathrm{K}$ and contribute to improving the physical condition of soil (Howeler 2000). Large amounts of manures were perhaps economical only if the manures were available locally; otherwise, application and transportation costs might be higher than the costs of chemical fertilizers.

Human Capital: On average, age of household heads of non-contractors was 49.04 years slightly higher than contractors, which were 48.83 years. The responses show that the female household heads who of contractors was much higher than non-contractors, reflecting the fact that Thai women are more likely to go for further study in higher education (Office of Women's Affairs and Family Development 2007), especially in under contract farmers' families. However, the mean of average years of education are highly significantly different with a significance level of 99\%. According to the Office of the National Economic and Social Development Board (2009), households whose heads were uneducated or had only primary education were found to be poorer than households whose heads had secondary education upwards. Thus, non-contractors who earned lower incomes compared to contractors poorer and their average of formal schooling years was lower. Further, in 2012, there were 305 agricultural groups and 38 agricultural cooperatives in Nakhon Ratchasima province (Cooperative Promotion Department 2012). Moreover, there is Bank for Agriculture and Agricultural Cooperatives (BAAC), which as a state enterprise under the jurisdiction of the Ministry of Finance extend credit more widely, directly to individual farmers as well as through farmer institutions and the National Village and Urban Community Fund, which is a learning centre fund and promotes the welfare of villages and communities. Household heads of contractors had belonged to agricultural organisations of 2.29 groups and 10.67 years of participation. The means of group numbers are highly significantly different with a significance level of $99 \%$ but years of participation are not significantly different.

Cassava Incomes and Gross Margin: The data from the research area showed large significant differences between the contractors and non-contractors in production activities. The cost of one kilogram of cassava products of non-contractors was calculated to be 1.46 baht, while it was 1.11 baht for contractors. When the average selling price of cassava in one kilogram of non-contractors was 2.38 baht, 0.92 baht of profit per kilo was made. The percentage of gross margin to the selling price was $52.99 \%$ in cash. In contrast, the percentage of gross margin to the selling price was $69.61 \%$ in cash.

Table 2: Income of Non-contractors and Contractors

\begin{tabular}{lll}
\hline Income & Non-contractors & Contractors \\
\hline Cassava income (baht/rai) & $9,860.41$ & $12,230.83$ \\
Gross margins (baht/rai) & $5,171.98$ & $8,505.78$ \\
Off-farm incomes (baht/year) & $79,947.69$ & $50,834.65$ \\
Tree crop incomes (baht/year) & $6,840.92$ & - \\
Livestock incomes (baht/year) & $2,822.31$ & 156.49 \\
\hline
\end{tabular}

Source: Calculated from the survey

\section{Determinants of contract participation}

- Female household heads have greater likelihood of participation in contract farming under cooperatives than male household heads. Women contractors of cassava in Thailand have a large farm size worked completely by local hired machinery and labourers. The husbands support the women in various ways in order to obtain influence in decisions regarding the cassava process. The women also grow cassava together with their husbands on their family farms and this cassava production is

2 The using fertilizer numbers with an NPK rating of 15-15-15, this fertilizer has $15 \%$ of each of Nitrogen, Phosphorus and Potassium. 
completely controlled by both women and their husbands.

- Number of agricultural groups was highly significant and positive which indicates that, if smallholders participate in one or more agricultural groups, the probability in contract farming under cooperatives will increase $21.15 \%$. Studies by Kureh \& Menkir (2006) indicate that in agricultural organizations are believed to be centre of information which can be accessed by households. Members and individuals are also motivated by other farmers to participate in beneficial groups such as contract farming under cooperatives. In addition, a number of agricultural groups to impart useful information to farmers could result in increased knowledge, productivity and income.

Table 3: Determinants of Contract Participation

\begin{tabular}{lll}
\hline Explanatory variables & \multicolumn{2}{c}{ Logit model } \\
\cline { 2 - 3 } & Coef. & $\mathbf{z}$ \\
\hline${ }^{1}$ Gender of household head & $-2.5649^{* * *}$ & -4.43 \\
Age of household head (years) & $0.01187^{\text {ns }}$ & 0.52 \\
Schooling year of household members (baht) & $0.3632^{* *}$ & 2.43 \\
Asset value (baht) & $0.000001^{\text {ns }}$ & 1.40 \\
Cassava planting area (rai) & $0.0059^{\text {ns }}$ & 0.94 \\
Number of agricultural groups (groups) & $2.1151^{* * *}$ & 4.81 \\
Input costs (baht/rai) & $-0.0015^{* *}$ & -2.28 \\
Labour expenses (baht.rai) & $-0.0018^{\text {ns }}$ & -1.16 \\
Machinery costs (baht) & $0.0022^{* * *}$ & 4.21 \\
Cassava income (baht.rai) & $0.0002^{* * *}$ & 3.12 \\
${ }^{2}$ Credit access & $-1.0529^{*}$ & -1.66 \\
Constant & $-9.8906^{* * *}$ & -4.14 \\
\hline
\end{tabular}

Wald $\mathrm{Chi}^{2}=66.49 ;$ Prob $>\mathrm{Chi}^{2}=0.0000$ and Pseudo $\mathrm{R}^{2}=0.7214$

${ }^{1} \mathrm{Gender}$ and ${ }^{2} \mathrm{Credit}$ is for discrete change of dummy variables from 0 and 1

***: significant at the $99 \%$ level; **: significant at the $95 \%$ level; *: significant at the $90 \%$ level and ns: significant at less than $90 \%$

Source: Calculated from the survey

- Machinery costs, including hiring tractors for land preparation, planting, harvesting and transportation, increases the probability of participation.

- The increasing of a thousand baht in cassava income increases the probability in contract farming by $20 \%$. It can be noted that farmers get more than 0.05 baht per kilo of cassava production if they sell their products though agricultural cooperatives which are contracted to the firms. Thus, participating in contract farming under cooperatives can increase income and as such, richer households may be better disposed toward participating in contract farming.

- The farmers who do not get credit from financial institutions have an opportunity to participate in contract farming more than the farmers who have access to credit. This indicates that contractors received credit in form of advance of capital inputs and services. Loans are usually given on the security of the anticipated value of the export crop or the land. Loan recoveries are usually made from as service charges or crop sales. Sometimes the farmers get loans separately from an existing a bank or credit agency, in which case the contract itself can serve as collateral.

- The household members' level of education was found to positively influence farmers' likelihood to participate in contract participation. This means that farmers who complete higher education would find it easier to understand the information given when receiving advice from the extension agents. Moreover, technical assistance and knowledge transfer can spill over onto adjacent fields and into nearby villages.

- Input costs including chemical fertilizer, herbicide, pesticide and manure for cassava production influence to participation. This indicates that lower production costs may make it more attractive for farmers to participate in contract farming under cooperatives.

Discussion: The main focus of this study has been on the impact of contract participation on the living standards for smallholders. There was evidence that contract farming can be viewed as an alternative way to improve living standard. Contract farming can be used as an intermediate step in the transition from subsistence to modern production. However, government policy is one of the most important problems on cassava production for ethanol processing, as the price of ethanol can be more competitive 
than gasoline; if the government supports ethanol, lower income smallholders may face difficulty in participating in contract farming. Therefore, if barriers to participation in contract farming for lower income smallholders are not reduced by making them more attractive to agribusiness firms then contract farming may only benefit wealthy smallholders.

\section{Conclusion}

There was a verbal agreement between farmers and agricultural cooperatives and a written contract agreement between agricultural cooperatives and processors. Thus, there was no written agreement between farmers and agricultural cooperatives. On the other hand, agricultural cooperatives would benefit 0.03 baht per kilogram of fresh cassava if farmers sell their products through co-operatives and farmers would get 0.05 baht per kilogram. Moreover, cassava represents a totally new market that will possibly increase significantly in the future as fuel reserves run out. Cassava farmers have a guaranteed market for their crops due to their products being part of a bio-fuel production chain. Seven variables, which significantly influence to cassava contract participation, are gender of household head, number of agricultural groups (groups), machinery costs (baht), cassava income (baht/rai), schooling year of household members (baht), input costs (baht/rai) and credit access.

Recommendations: The main focus of this study has been on the impact of contract participation on the living standards for smallholders. There was evidence that contract farming can be viewed as an alternative way to improve living standard, particularly when underemployment on family farms occurs. Contract farming can be used as an intermediate step in the transition from subsistence to modern production. However, government policy is one of the most important problems on cassava production for ethanol processing, as the price of ethanol can be more competitive than gasoline; if the government supports ethanol, lower income smallholders may face difficulty in participating in contract farming due to the ownership of human capital and physical assets. Therefore, if barriers to participation in contract farming for lower income smallholders are not reduced by making them more attractive to agribusiness firms then contract farming may only benefit wealthy smallholders.

\section{References}

Baumann, P. (2000). Equity and Efficiency in Contract Farming Schemes: The Experience of Agricultural Tree Crops, London: Overseas Development Institute.

Bell, D. R. \& Silalertruksa, T. (2010). The Net Cost of Biofuels in Thailand-An economic analysis. Energy Policy, 39, 834-843.

Bloyd, C. N. (2009). An Update on Ethanol Production and Utilization in Thailand. U.S. Department of Energy, Washington: Pacific Northwest National Laboratory.

Cooperative Promotion Department. (2012). Agricultural Groups in Nakhon Ratchasima Province 2012, Bangkok: Ministry of Agriculture and Cooperatives.

Crown, W. H. (1998). Statistical Models for the Social and Behavioral Sciences: Multiple Regression and Limited-Dependent Variable Models, Connecticut: Praeger Publishers.

Department of Agriculture Extension. (2011). The Registeration of Cassava Farmers in Nakorn Ratchasima District in 2011. Nakorn Ratchasima, Thailand, Department of Agriculture Extension, Bangkok: Ministry of Agricultre and Cooporatives.

Department of Export Promotion. (2010). Cassava and the Future of Thailand's Biofuel Industry, Bangkok: Ministry of Commerce.

Ellis, F. \& Biggs, S. (2002). Evolving Themes in Rural Development 1950s-2000s. Development policy review, 19(4), 437-448.

Fabra, U. P. \& Schmidheiny, K. (2010). Binary Response Models: Short Guides to Micro econometrics, Basel: Unversity of Basel.

George, J. \& Mohankumar, C. (2000). Cassava Agronomy Research and Adoption of Improved Practices in India Major. Achievements During the Past 30 Years, 258-276.

Glover, D. (1990). Contract Farming and Commercialization of Agriculture in Developing Countries, 166175.

Guo, H. \& Jolly, R. W. (2009). Contract Farming in China: Perspectives of Smallholders.

2009 Conference, August 16-22, 2009, Beijing, China, International Association of Agricultural Economists, 3-12.

Hazell, P. \& Poulton, C. (2006). The Future of Small Farms: Synthesis Paper, World Bank, London: Imperial College London. 
Howeler, R. \& Oates, C. (2000). Strategic Environmental Assessment: Assessment of the Impact of Cassava Production and Processing on the Environment. Draft Report Prepared for the International Fund for Agricultural Development, 4-8.

Howeler, R. H. (2000). Cassava Agronomy Research in Asia: Has It Benefited Cassava Farmers, 345-382.

Howeler, R. H. (2007). Production Techniques for Sustainable Cassava Production in Asia, 1-13.

Kuiper, L. \& Ekmekci, B. (2007). Bio-Ethanol from Cassava. Ecofys Netherlands BV, 1-29.

Kureh, I. \& Menkir, A. (2006). Participatory On-farm Evaluation of the Performance of Drought-Tolerant Maize Varieties in the Guinea Savannas of Nigeria. International Journal of Food, Agriculture and Environment, 4(1), 192-196.

Martinez, S. W. \& Reed, A. (1996). From Farmers to Consumers: Vertical Coordination in the Food Industry, US Department of Agriculture, 2-18.

Masakure, O. \& Henson, S. (2005). Why Do Small-Scale Producers Choose to Produce Under Contract? Lessons From Nontraditional Vegetable Exports From Zimbabwe. World Development 33(10), 1721-1733.

Morrison, P. S. \& Murray, W. E. (2006). Promoting Indigenous Entrepreneurship Through Small-Scale Contract Farming: The Poultry Sector in Sarawak, Malaysia. Singapore Journal of Tropical Geography, 27(2), 191-206.

Nguyen, T. L. T. \& Gheewala, S. H. (2008). Life Cycle Cost Analysis of Fuel Ethanol Produced From Cassava in Thailand. The International Journal of Life Cycle Assessment, 13(7), 564-573.

Nishimura, H. (2003). Agribusiness Development in Asia and the Pacific with Emphasis on Indonesia, Malaysia, The Philippines and Thailand. Development of Agribusiness Enterprises (Japan), 17-30.

Nualvatna, K. (2003). Development of Agribusiness Enterprises: Thailand. Development of Agribusiness Enterprises (Japan), 166-174.

Office of Agricultural Economics. (2007). An Agricultural Farmers' Situation in Thailand 2006-2007, Bangkok: Ministry of Agriculture and Cooperatives.

Office of Agricultural Economics. (2008). Industrial Cassava: Area, Production and Yield by Region and Province, 2006-2008. Office of Agricultural Economics, Bangkok: Ministry of Agriculture and Cooperatives.

Office of Agricultural Economics. (2011). Industrial Cassava: Area, Production and Yield by Region and Province 2009-2010, Bangkok: Ministry of Agriculture and Cooperatives.

Office of the National Economic and Social Development Board. (2009). National Report Thailand: Global Sttudy on Child Poverty and Disparities, Office of the National Economic and Social Development Board, Bangkok: United Nations Children's Fund (UNICEF).

Office of Women's Affairs and Family Development. (2007). General Situation of Women in Thailand, Bangkok: Ministry of Social Development and Human Security.

Preechajarn, S. \& Prasertsri, P. (2010). Thailand Biofuels Annual Annual 2010, Bangkok: U.S. Department of Agriculture.

Prowse, M. \& Thirion, M. C. (2012). Contract Farming in Developing Countries. A Review. Agence Française de Développement, Paris: Imprimerie de Montligeon.

Senadee, W. \& Aksornneum, K. (2008). Cassava: Valuable Products. House Agricultural Magazine. Thailand, House Agricultural Magazine, 7-44.

Seumpakdee, S. (2009). The Thai Industries of Ethanol: Problems, Treat and the Development and Extention. Thai Tapioca Starch Association (TTSA) 2009, 12-38.

Singh, S. (2011). Role of the State in Contract Farming in Thailand: Experience and Lessons. ASEAN Economic Bulletin, 22(2), 217-228.

Sriroth, K. \& Piyachomkwan, K. (2008). Cassava Ethanol technology and growth in Thailand. Bangkok, Kasetsart Universtity, 26-42.

Suthamma, S. \& Chumnong, Y. (2011). Life Cycle Cost of Ethanol Production From Cassava in Thailand. Renewable and Sustainable Energy Reviews, 15(2), 1343-1349.

Swinnen, J. F. \& Maertens, M. (2007). Globalization, Privatization, and Vertical Coordination in Food Value Chains in Developing and Transition Countries. Agricultural Economics, 37, 89-102.

Train, K. E. (1995). Simulation Methods for Probit and Related Models Based on Convenience Error Partitioning. University of California, 1-34.

Young, L. M. \& Hobbs, J. E. (2002). Vertical Linkages in Agri-Food Supply Chains: Changing Roles for Producers. Commodity Groups, and Government Policy. Review of Agricultural Economics, 24(2), 428-441.

Zhang, C. \& Han, W. (2003). Life Cycle Economic Analysis of Fuel Ethanol Derived From Cassava in Southwest China. Renewable and Sustainable Energy Reviews, 7(4) 353-366. 